\title{
Mesenchymal stem cells and JIA
}

\author{
JF Swart ${ }^{1 *}$, S de Roock ${ }^{1}$ F Hofhuis ${ }^{2}$, W Kuis ${ }^{1}$, BJ Prakken ${ }^{1}$, AC Martens ${ }^{2}$, I Slaper-Cortenbach ${ }^{2}$, NM Wulffraat ${ }^{1}$ \\ From 18th Pediatric Rheumatology European Society (PReS) Congress \\ Bruges, Belgium. 14-18 September 2011
}

\section{Background}

Mesenchymal stem cells (MSC) are adult stem cells present in bone marrow (BM), fat and in many other tissues. MSC have strong immunosuppressive qualities in vitro. The immunosuppression seems to work both by paracrine action and cell-cell contact. MSC inhibit NKcells, B-cells, dendritic cells, Th1-cells and activate regulatory T-cells. The presence of floating single MSC in human synovial fluid (SF) is a normal phenomenon and the number of MSC in SF is much lower in RA than in osteoarthritis (OA). SF in RA might be impaired in recruiting MSC to the joint and the proliferation potential of MSC in RA patients could be suppressed by the synovitis or be exhausted as suggested by the decreased telomere length. Administration of additional MSC might therefore have great potential in the treatment of inflammatory arthritis as we and others have shown in different experimental arthritis models.

\section{Aim}

To evaluate the presence and number of MSC in SF of JIA patients and to see if addition of healthy MSC was capable of immunosuppression of the synovial T-cells in JIA patients.

\section{Methods}

We used the criteria of the ISCT [Horwitz EM etal. Cytotherapy. 2005;7(5):393-5.] to culture the MSC and used CFSE staining for lymphocytes and our standard setting for suppression with regulatory $\mathrm{T}$-cells as described [Vercoulen Y etal. Plos One 2009; 4(9)].

\section{Results}

In JIA patients we find around $5-10 \times 10^{6}$ cells per milliliter SF with 1.2-2.4 $\times 10^{6} \mathrm{CD} 4+$ cells and 1.6-3.2 $\times 10^{6}$

\footnotetext{
* Correspondence: jswart@umcutrecht.nl

'Department of Pediatric Immunology, Wilhelmina Children's Hospital/

UMCU, Utrecht, Netherlands

Full list of author information is available at the end of the article
}

CD8+ cells per ml. In the SF of arthritic knees from 14 JIA patients we found mesenchymal stem cells at a low rate: a median of 4 CFU-F (with a maximum of 81 CFU-F) per million SF cells [normal healthy SF contains 250 CFU-F per 1 million SF cells]. We found that adding allogeneic healthy BM derived MSC to anti-CD3 stimulated SF cells of JIA patients showed dose dependent suppression of SF CD4+ and CD8+ T cell proliferation (Fig 1).

\section{Conclusion}

A low number of CFU-F were found in the SF of JIA patients. The addition of allogeneic MSC to SF of JIA patients suppressed the synovial CD4+ and CD8+ T cell proliferation. A ratio of 1 MSC per $5 \mathrm{CD} 4+$ or $5 \mathrm{CD} 8+$ cells already yielded good results.

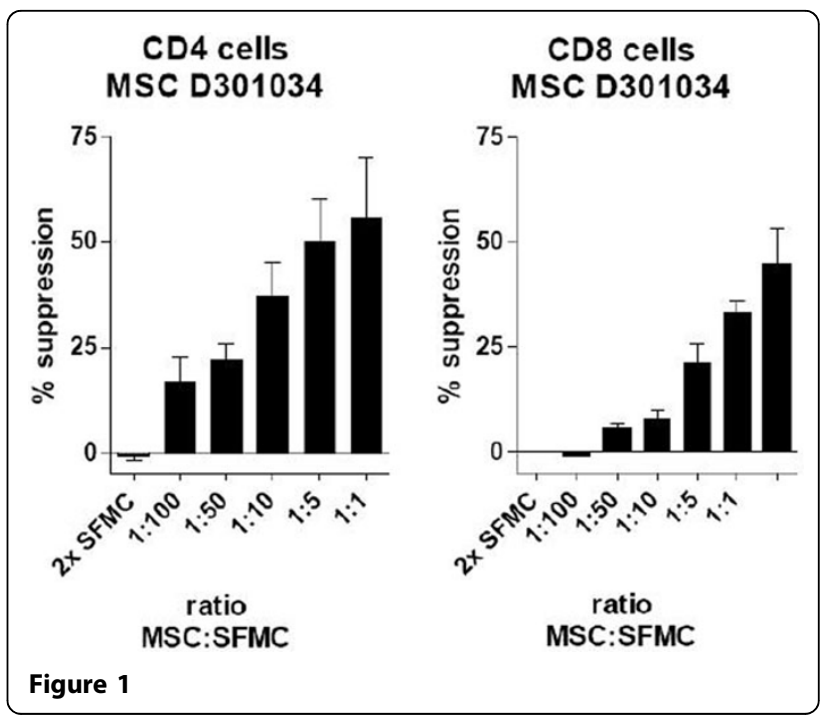

(c) 2011 Swart et al; licensee BioMed Central Ltd. This is an open access article distributed under the terms of the Creative Commons 


\section{Author details}

'Department of Pediatric Immunology, Wilhelmina Children's Hospital/

UMCU, Utrecht, Netherlands. ${ }^{2}$ Department of Immunology, UMC Utrecht,

Utrecht, Netherlands.

Published: 14 September 2011

doi:10.1186/1546-0096-9-S1-P65

Cite this article as: Swart et al:: Mesenchymal stem cells and JIA.

Pediatric Rheumatology 2011 9(Suppl 1):P65.

Submit your next manuscript to BioMed Central and take full advantage of:

- Convenient online submission

- Thorough peer review

- No space constraints or color figure charges

- Immediate publication on acceptance

- Inclusion in PubMed, CAS, Scopus and Google Scholar

- Research which is freely available for redistribution 